\title{
Lipomyces orientalis sp. nov., a yeast species isolated from soil in Vietnam
}

\author{
Vu Nguyen Thanh
}

Correspondence

Vu Nguyen Thanh

thanh@firi.ac.vn
Department of Microbiology, Food Industries Research Institute, 301-Nguyen Trai, Thanh Xuan, Hanoi, Vietnam

\begin{abstract}
Five strains of the novel ascogenous yeast species Lipomyces orientalis sp. nov. were isolated from soil samples collected in Vietnam. The yeast forms asci containing one to four ascospores. The ascospores of $L$. orientalis have warty surfaces and differ from the characteristic striated ascospores of Lipomyces tetrasporus. Phylogenetic analyses of D1/D2 26S rDNA and ITS sequences indicate that $L$. orientalis and $L$. tetrasporus are closely related, but they differ from each other by 6 nucleotides in the D1/D2 region and 16 nucleotides in the ITS region. The type culture is strain Lip $95^{\top}\left(=\right.$ CBS $10300^{\top}=$ NRRL Y-27927 $7^{\top}$.
\end{abstract}

Yeasts of the genus Lipomyces are true soil inhabitants and have a worldwide distribution. The genus Lipomyces and associated genera (Dipodascopsis, Zygozyma, Myxozyma) represent a unique branch in the evolution of the ascomycetes (van der Walt, 1992). Currently 11 species of Lipomyces are recognized, Lipomyces doorenjongii, L. japonicus, $L$. kockii, L. kononenkoae, L. lipofer, L. mesembrius, L. spencermartinsiae, L. starkeyi, L. tetrasporus, L. yamadae and L. yarrowii (van der Walt et al., 1997; Smith, 1998; van der Walt et al., 1999). Despite the worldwide distribution of the genus, some geographical and geochemical preferences have been recorded for some species. For example, L. lipofer is restricted to temperate zones (Canada, Russia) whereas L. kononenkoae and L. spencermartinsiae can be commonly found in ferric soils of the tropics (Mali, Nigeria, Trinidad) (Babjeva \& Gorin, 1987). In a survey of the diversity of soil yeasts in Vietnam, strains representing a novel species of the genus Lipomyces were isolated.

A total of 52 soil samples from different locations in Vietnam were collected and analysed (see Supplementary Fig. S1 for locations of sampling sites). For isolation of lipomycetaceous yeasts, soil particles were sprinkled over agar plates containing nitrogen-depleted medium $\left(1^{-1}: 20 \mathrm{~g}\right.$ glucose, $20 \mathrm{~g}$ agar, 0.85 $\mathrm{g} \mathrm{KH}_{2} \mathrm{PO}_{4}, 0.15 \mathrm{~g} \mathrm{~K}_{2} \mathrm{HPO}_{4}, 0.5 \mathrm{~g} \mathrm{MgSO}_{4} .7 \mathrm{H}_{2} \mathrm{O}$, $0.1 \mathrm{~g} \mathrm{NaCl}, 0.1 \mathrm{~g} \mathrm{CaCl}_{2} \cdot 6 \mathrm{H}_{2} \mathrm{O}, 0.5 \mathrm{mg} \mathrm{H}_{3} \mathrm{BO}_{3}, 0.04 \mathrm{mg}$ $\mathrm{CuSO}_{4} \cdot \mathrm{H}_{2} \mathrm{O}, 0.1 \mathrm{mg} \mathrm{KI}, 0.2 \mathrm{mg} \mathrm{FeCl}_{3} \cdot 6 \mathrm{H}_{2} \mathrm{O}, 0.4 \mathrm{mg}$ $\mathrm{MnSO}_{4} \cdot \mathrm{H}_{2} \mathrm{O}, 0 \cdot 2 \mathrm{mg} \mathrm{Na}_{2} \mathrm{MoO}_{4} \cdot 2 \mathrm{H}_{2} \mathrm{O}, 0 \cdot 4 \mathrm{mg} \mathrm{ZnSO}_{4}$.

The GenBank/EMBL/DDBJ accession number for the $26 \mathrm{~S}$ rDNA D1/D2 and ITS sequences of strain Lip $95^{\top}$ are DQ275615 and DQ275616.

A protocol for the preparation of malt broth, a map showing the locations of the sampling sites, an electron micrograph of ascospores of strain Lip $95^{\top}$ and a neighbour-joining tree based on D1/D2 sequences are available as supplementary material in IJSEM Online. $\left.7 \mathrm{H}_{2} \mathrm{O}\right)$. The plates were incubated at $25^{\circ} \mathrm{C}$ for $2-3$ weeks until characteristic slimy growth of Lipomyces was detected. Yeast colonies were purified on the nitrogen-depleted medium and then on malt/glucose agar $\left(1{ }^{\circ} \mathrm{Bx}\right.$ malt broth, $1 \%$ glucose, $2 \%$ agar). A protocol describing the preparation of the malt broth is available as supplementary material in IJSEM Online.

Lipomycetaceous yeasts were found in 24 of the 52 samples. From these, 73 strains were isolated. They all sporulated strongly on diluted malt/glucose agar after 3-4 weeks of incubation. The strains were divided into groups based on the mode of ascospore formation. Twenty-four strains were found to be of the 'tetrasporus' type (i.e. they formed asci containing one to four ascospores). The remaining strains produced asci containing mainly more than eight ascospores. Among the 'tetrasporus' group, 19 strains produced striated ascospores and the other five produced roughened ascospores (Fig. 1a). Closer examination by scanning electron microscopy (SEM) revealed that ascospores of the latter five strains had warty surfaces (Fig. 1b and Supplementary Fig. S2) and, thus, they differed morphologically from all known Lipomyces species.

Physiological tests were carried out on the latter five strains using standard methods for yeast characterization (Yarrow, 1998). Sporulation of strains was obtained on 10 -fold diluted malt/glucose agar $\left(0 \cdot 1{ }^{\circ} \mathrm{Bx}\right.$ malt broth, $0 \cdot 1 \%$ glucose, $2 \%$ agar). The morphology of vegetative cells and ascospore formation was studied using a light microscope (Eclipse E600; Nikon). Photographs were taken with a digital video camera (TK-C1380E; JVC). For SEM, strongly sporulated biomass was collected and fixed with $10 \%$ glutaraldehyde for $2 \mathrm{~h}$. The biomass was then treated with increasing concentrations of acetone $(25,50,75$ and $100 \%)$ and dried. The samples were coated with gold and viewed with scanning electron microscope (JSM-5410LV; JEOL) at $15000 \mathrm{kV}$. 

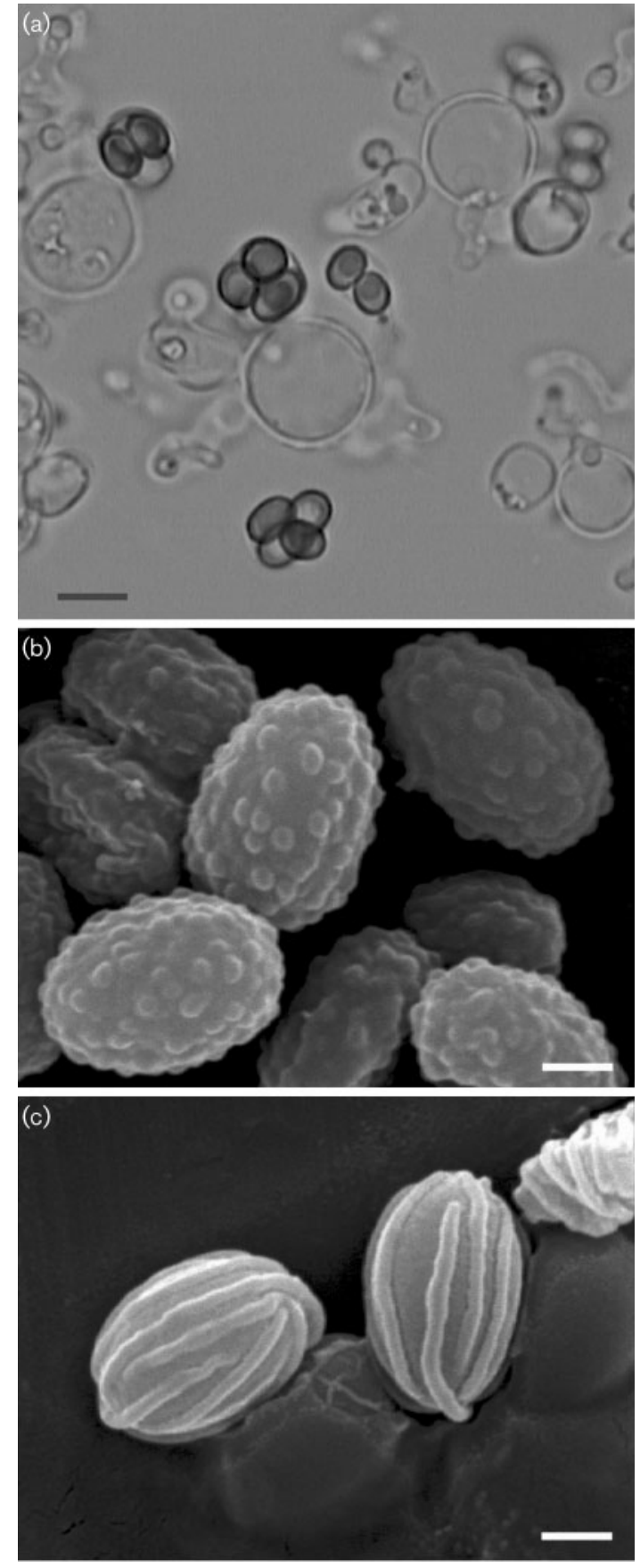

Fig. 1. (a) Asci and ascospores of Lipomyces orientalis sp. nov. Lip $95^{\top}$ grown on diluted malt/glucose agar for 4 weeks at $25^{\circ} \mathrm{C}$. (b-c) Scanning electron micrographs of Lipomyces orientalis Lip $95^{\top}$ (b) and Lipomyces tetrasporus Lip 5 (c) grown on diluted malt/glucose agar for 4 weeks. Bars, $5 \mu \mathrm{m}$ (a) and $1 \mu \mathrm{m}(\mathrm{b}, \mathrm{c})$.

The five novel strains differed from the standard description of $L$. tetrasporus in three assimilation tests (assimilation of propane-1,2-diol, butane-2,3-diol and nitrite). These five lipomycetaceous strains were isolated from three soil samples collected at Thanh Hoa (strain MD66-1), Quang
Ninh (strains MD88-4 and MD 89-4) and Nha Trang (strains Lip 51 and Lip 95 $5^{\mathrm{T}}$ ) (Table 1). The distances between these locations are roughly 260, 940 and $1000 \mathrm{~km}$.

Extraction and purification of the coenzyme Q system were performed according to Yamada \& Kondo (1973). Reversedphase HPTLC was used for identification of coenzyme Q. Reversed-phase HPTLC plates (silica gel 60 for nano TLC; Merck) were prepared by dipping in $\mathrm{n}$-hexane containing $5 \%$ liquid paraffin. The plates were air-dried. Coenzyme Q samples and standards were spotted on the plates, which were then developed with methanol/isopropanol $(1: 1)$ saturated with liquid paraffin. Visualization was done by dipping the plates in $0 \cdot 2 \% \mathrm{KMnO}_{4}$ for $5 \mathrm{~min}$. This procedure ensures good separation of CoQ-6, CoQ-7, CoQ-8, CoQ-9 and CoQ-10. To separate CoQ-10 and CoQ-10 $\left(\mathrm{H}_{2}\right)$, a developing system containing acetone/acetonitrile $(1: 1)$ saturated with liquid paraffin was used. The major ubiquinone of the novel strains was Q-9.

For DNA extraction, strain Lip $95^{\mathrm{T}}$ was grown on YMA $(0.3 \%$ yeast extract, $0.3 \%$ malt extract, $0.5 \%$ peptone, $1 \%$ glucose, $2 \%$ agar) for 3 days at $25^{\circ} \mathrm{C}$. One loopful of cells was transferred to a microfuge tube containing $1 \mathrm{ml} 2 \times$ SSC and heated at $99^{\circ} \mathrm{C}$ for $10 \mathrm{~min}$. Cells were collected and washed once with $1 \mathrm{ml}$ sterile deionized water by centrifugation. To the cell pellet, about $75 \mu \mathrm{l}$ glass beads $(0 \cdot 2-0.5 \mathrm{~mm}$ in diameter $), 75 \mu \mathrm{l} \mathrm{phenol/chloroform} \mathrm{and}$ $100 \mu \mathrm{l}$ water were added. The tube was shaken at 1400 r.p.m. for $10 \mathrm{~min}$ and then centrifuged at $10000 \mathrm{~g}$ for $10 \mathrm{~min}$. The upper layer was transferred to a new microfuge tube and used directly as template for PCR. Due to the well-known inhibition effect of slimy substances of Lipomyces on the PCR (Nishimura et al., 2002), care is needed regarding the age of culture and the cultivation medium.

The ITS-D1/D2 region was amplified using primers ITS1 and NL4 on a GeneAmp PCR System 9700 (PE Applied Biosystems). The PCR conditions were as follows: an initial denaturation step of $94^{\circ} \mathrm{C}$ for $3 \mathrm{~min}$ followed by 30 cycles of $94{ }^{\circ} \mathrm{C}$ for $30 \mathrm{~s}, 52^{\circ} \mathrm{C}$ for $40 \mathrm{~s}$ and $72^{\circ} \mathrm{C}$ for $60 \mathrm{~s}$, with a final extension step at $72^{\circ} \mathrm{C}$ for $7 \mathrm{~min}$. The PCR product was purified by using a QIAEX II agarose gel extraction kit (Qiagen). The DNA was sequenced by the dideoxy chaintermination method using primers ITS1, ITS4, NL1 and NL4 described by Kurtzman \& Robnett (1998) and EsteveZarzoso et al. (1999). A model 377 automated DNA sequencer (Applied Biosystems) was used. For phylogenetic analyses, the resulting sequences were compared with known sequences in GenBank using the web-based nucleotide-nucleotide BLAST search engine hosted by the National Center for Biotechnology Information (http://www.ncbi.nlm.nih.gov) (Altschul et al., 1997). The most similar sequences were edited using the program BioEdit (Hall, 1999) and aligned using CLUSTAL X version 1.81 (Thompson et al., 1997). The fixed-gap and floating-gap penalty values used were respectively 10 and $0 \cdot 2$. Phylogenetic trees were constructed from distance data transformed according to Kimura (1980), using the neighbour-joining method (Saitou \& Nei, 1987) in 
Table 1. Isolation sources of strains of Lipomyces orientalis sp. nov.

\begin{tabular}{|c|c|c|}
\hline Strain & Other collection numbers & Source of isolation \\
\hline Lip 51 & CBS 10301, NRRL Y-27928 & $\begin{array}{l}\text { Mixed forest soil, hillside (bottom part), } 50 \mathrm{~m} \text { from water edge, } \\
\text { Bai San island, Nha Trang }\end{array}$ \\
\hline Lip $95^{\mathrm{T}}$ & CBS $10300^{\mathrm{T}}$, NRRL Y-27927 ${ }^{\mathrm{T}}$ & $\begin{array}{l}\text { Mixed forest soil, hillside (bottom part), } 50 \mathrm{~m} \text { from water edge, } \\
\text { Bai San island, Nha Trang }\end{array}$ \\
\hline MD66-1 & CBS 10302, NRRL Y-27929 & Grassland soil, hillside (bottom part), Cam Thuy, Thanh Hoa \\
\hline MD88-4 & CBS 10303, NRRL Y-27930 & $\begin{array}{l}\text { Mixed forest soil, hillside (bottom part), } 100 \mathrm{~m} \text { from water edge, } \\
\text { Cat Ba island, Quang Ninh }\end{array}$ \\
\hline MD $89-4$ & CBS 10304, NRRL Y-27931 & $\begin{array}{l}\text { Mixed forest soil, hillside (bottom part), } 100 \mathrm{~m} \text { from water edge, } \\
\text { Cat Ba island, Quang Ninh }\end{array}$ \\
\hline
\end{tabular}

CLUSTAL X. Bootstrap analyses were performed from 1000 random resamplings (Felsenstein, 1985). The phylogenetic tree was displayed using TreeExplorer version 1.21 (which can be downloaded from http://evolgen.biol.metro-u.ac.jp/ pub/MolEvol/TE212.zip). Sequences from Stephanoascus smithiae strains NRRL Y-17849 (GenBank accession no. U76531) and CBS 5657 (AJ606463) were used as the outgroups for the D1/D2 and ITS trees, respectively.

ITS and 26S rDNA D1/D2 sequences were obtained for strain Lip $95^{\mathrm{T}}$. In the phylogenetic tree constructed based on D1/D2 sequences, Lip $95^{\mathrm{T}}$ clustered with L. kononenkoae, L. spencermartinsiae, L. starkeyi and L. tetrasporus but formed an out-branch (see Supplementary Fig. S3 in IJSEM Online). In the D1/D2 region, Lip $95^{\mathrm{T}}$ was closest to L. tetrasporus but differed from the latter at six positions (five substitutions and one insertion). In the ITS tree, Lip $95^{\mathrm{T}}$ clustered with L. tetrasporus (Fig. 2). They differed from each other at 16 positions in the ITS region. Based on the distinctive phenotypic characteristics and phylogenetic position amongst established taxa, a novel species of Lipomyces, Lipomyces orientalis sp. nov., is proposed to accommodate the new isolates.

\section{Latin diagnosis of Lipomyces orientalis Thanh sp. nov.}

In YMA ad $25^{\circ} \mathrm{C}$ post dies tres cellulae singulae, binae, ovoidae, 4-9 $\times 5-12 \mu \mathrm{m}$. In agaro malti cultura aquosa mucosescens, partim cremea, impellucida, glabra, nitida, margine integro. In agaro farinae Zeae maydis confecto post decemduum in $25^{\circ} \mathrm{C}$ hyphae et pseudohyphae nullae. In medio liquido post unum mensem ad $25^{\circ} \mathrm{C}$, sedimentum formatur. Asci plerumque affixi, saccati vel tortioter tubilares, pariete tarde deliquescente. Ascosporae maturae ellipsoideae, succinae, verrucosae, $2 \cdot 2-2 \cdot 7 \times 3 \cdot 2-3 \cdot 9 \mu \mathrm{m}, 1-4$ in asco, conglutinantes ubi liberatae. Fermentatio nulla. D-Glucosum, D-galactosum, L-sorbosum, D-xylosum, L-arabinosum (exiguum vel non), D-arabinosum (exiguum), L-rhamnosum (fortasse exiguum), sucrosum, maltosum, $\alpha, \alpha$-trehalosum (exiguum), methyl- $\alpha$-Dglucosidum, cellobiosum (fortasse exiguum), salicinum (fortasse exiguum), arbutinum (exiguum), melibiosum (fortasse exiguum), lactosum (exiguum vel non), raffinosum, melezitosum, inulinum, amylum solubile (exiguum), erythritolum, ribitolum (lente et exiguum), xylitolum, D-glucitolum, D-mannitolum, galactitolum, D-glucono-1,5-lactonum (exiguum), 2-keto-Dgluconatum, 5-keto-D-gluconatum (exiguum), D-gluconatum

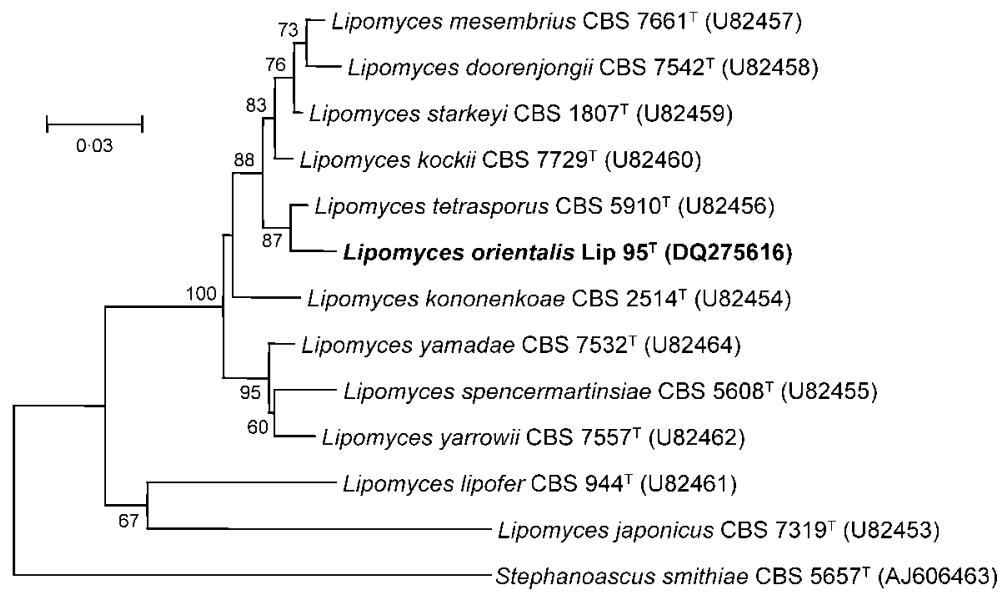

Fig. 2. Neighbour-joining tree depicting the relationships between Lipomyces orientalis and neighbouring taxa. The tree was constructed from nucleotide divergence in the ITS region using the program CLUSTAL $\mathrm{x}$. Bootstrapping was done with 1000 replications; values above $50 \%$ are given. Stephanoascus smithiae CBS $5657^{\top}$ was used as the outgroup. GenBank accession numbers are given after strain names. 


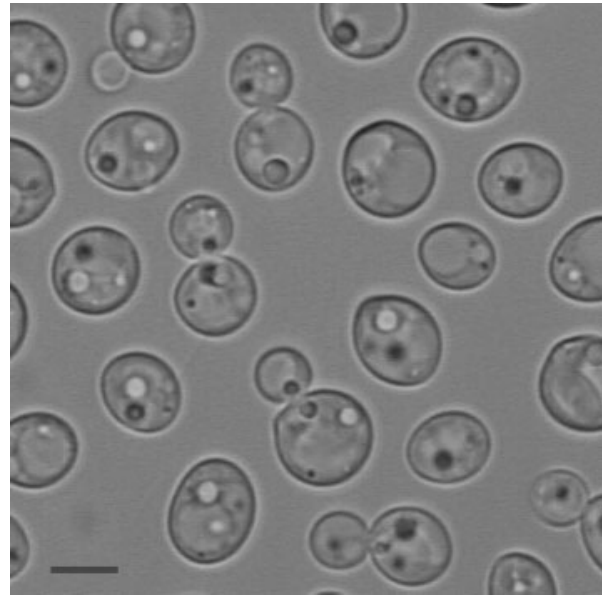

Fig. 3. Vegetative cells of Lipomyces orientalis Lip $95^{\top}$ grown on YMA for 3 days at $25^{\circ} \mathrm{C}$. Bar, $5 \mu \mathrm{m}$.

(exiguum), succinatum (exiguum), citratum (exiguum), et ethanolum (exiguum) assimilantur, at non D-glucosaminum, D-ribosum, glycerolum, myo-inositolum, D-galacturonatum, DL-lactatum, methanolum, propane-1,2-diolum, nec butane2,3-diolum. Natrium nitrosum, L-lysinum, glucosaminum, et imidazolum assimilantur, at non kalium nitricum. Materia amyloidea formatur. Ureum non hydrolysatur. Non crescit in $10 \% \mathrm{NaCl} / 5 \%$ glucoso. Crescere sine vitaminis. Crescit in $30{ }^{\circ} \mathrm{C}$, non crescit in $35^{\circ} \mathrm{C}$. Crescit in medio $1 \mathrm{mg}$ cycloheximido $\mathrm{ml}^{-1}$ addito. Ubiquinonum majus: Q-9. Typus: Lip $95^{\mathrm{T}}$ $\left(=\mathrm{CBS} 10300^{\mathrm{T}}=\mathrm{NRRL} \mathrm{Y}-27927^{\mathrm{T}}\right)$. Isolata a terra, ex Bai San, Nha Trang, Vietnam. Depositata in collectione zymotica Centraalbureau voor Schimmelcultures, Trajectum ad Rhenum.

\section{Description of Lipomyces orientalis Thanh sp. nov.}

Lipomyces orientalis (o.ri.en.tal'is. L. masc. adj. orientalis from the East, referring to the fact that the species was first isolated from soil in Vietnam).

On YMA after 3 days at $25^{\circ} \mathrm{C}$, cells are ovoidal, 4-9 $\times 5-$ $12 \mu \mathrm{m}$, and occur singly or in pairs (Fig. 3). The streak culture on malt agar is mucoid, partly hyaline, partly creamish-opaque, smooth and glistening, with an entire margin. In Dalmau plate cultures on cornmeal agar after 10 days at $25^{\circ} \mathrm{C}$, neither hyphae nor pseudohyphae are formed. In YM broth after 1 month at $25^{\circ} \mathrm{C}$, sediment is present. Asci are attached as a rule, saccate to irregularly tubular or contorted, with slowly deliquescent walls. Mature ascospores are ellipsoid, amber-coloured, warty, $2 \cdot 2-2 \cdot 7 \times$ $3 \cdot 2-3 \cdot 9 \mu \mathrm{m}$, one to four per ascus, and conglutinative when liberated (Fig. 1b). Does not ferment D-glucose. Assimilates D-glucose, D-galactose, L-sorbose, D-xylose, L-arabinose (weakly or not at all), D-arabinose (weakly), L-rhamnose (maybe weakly), sucrose, maltose, $\alpha, \alpha$-trehalose (weakly), methyl $\alpha$-D-glucoside, cellobiose (maybe weakly), salicin (maybe weakly), arbutin (weakly), melibiose (maybe weakly), lactose (weakly or not at all), raffinose, melezitose, inulin, starch (weakly), erythritol, ribitol (delayed and weakly), xylitol, D-glucitol, D-mannitol, galactitol, D-glucono-1,5-lactone (weakly), 2-keto-D-gluconate, 5-keto-Dgluconate (weakly), D-gluconate (weakly), succinate (weakly), citrate (weakly) and ethanol (weakly). Does not assimilate D-glucosamine, D-ribose, glycerol, myo-inositol, D-galacturonate, DL-lactate, methanol, propane-1,2-diol or butane-2,3-diol. Assimilates nitrite, L-lysine, glucosamine and imidazole. Does not assimilate nitrate. Produces starchlike substances. Urease reaction is negative. Does not grow in YNB medium (Difco) containing $10 \% \mathrm{NaCl}$ and $5 \%$ glucose. Grows in vitamin-free medium. Does not grow at $35^{\circ} \mathrm{C}$, but grows at $30^{\circ} \mathrm{C}$. Growth in medium containing $0 \cdot 1 \%$ cycloheximide is positive. The major ubiquinone is Q-9.

The type strain, Lip $95^{\mathrm{T}}\left(=\mathrm{CBS} 10300^{\mathrm{T}}=\mathrm{NRRL} Y-27927^{\mathrm{T}}\right.$ ), as well as strains Lip 51 (=CBS 10301=NRRL Y-27928), MD 66-1 (=CBS $10302=\mathrm{NRRL} \quad \mathrm{Y}-27929), \quad \mathrm{MD} \quad 88-4$ $(=\mathrm{CBS} 10303=\mathrm{NRRL} \mathrm{Y}-27930)$ and $\mathrm{MD}$ 89-4 (=CBS $10304=$ NRRL Y-27931), were isolated from uncultivated soil in Vietnam and have been deposited in the Yeast Collection of the Centraalbureau voor Schimmelcultures, Utrecht, The Netherlands, and the Agricultural Research Service Yeast Collection, US Department of Agriculture, Peoria, IL, USA.

\section{Acknowledgements}

This work was funded by the Ministry of Science \& Technology of Vietnam. The author thanks Hoang Thi Minh Nhat and Dao Anh Hai for helpful assistance.

\section{References}

Altschul, S. F., Madden, T. L., Schaffer, A. A., Zhang, J., Zhang, Z., Miller, W. \& Lipman, D. J. (1997). Gapped BLAST and PSI-BLAST: a new generation of protein database search programs. Nucleic Acids Res 25, 3389-3402.

Babjeva, I. P. \& Gorin, S. E. (1987). Soil Yeasts. Moscow: Moscow State University Press.

Esteve-Zarzoso, B., Belloch, C., Uruburu, F. \& Querol, A. (1999). Identification of yeasts by RFLP analysis of the $5 \cdot 8 \mathrm{~S}$ rRNA gene and the two ribosomal internal transcribed spacers. Int $J$ Syst Bacteriol 49, 329-337.

Felsenstein, J. (1985). Confidence limits on phylogenies: an approach using the bootstrap. Evolution 39, 783-791.

Hall, T. A. (1999). BIOEDIT: a user-friendly biological sequence alignment editor and analysis program for Windows 95/98/NT. Nucleic Acids Symp Ser 41, 95-98.

Kimura, M. (1980). A simple method for estimating evolutionary rates of base substitutions through comparative studies of nucleotide sequences. J Mol Evol 16, 111-120.

Kurtzman, C. P. \& Robnett, C. J. (1998). Identification and phylogeny of ascomycetous yeasts from analysis of nuclear large subunit (26S) ribosomal DNA partial sequences. Antonie van Leeuwenhoek 73, 331-371. 
Nishimura, K., Shimada, K., Iwasawa, H., Naganuma, T. \& Uzuka, Y. (2002). Total DNA preparation excluding extracellular acidic polysaccharide from Lipomyces yeasts and its application to taxonomic studies. Biosci Biotechnol Biochem 66, 1563-1566.

Saitou, N. \& Nei, M. (1987). The neighbor-joining method: a new method for reconstructing phylogenetic trees. Mol Biol Evol 4, 406-425.

Smith, M. Th. (1998). Lipomyces Lodder \& Kreger van Rij. In The Yeasts, a Taxonomic study, 4th edn, pp. 248-253. Edited by C. P. Kurtzman \& J. W. Fell. Amsterdam: Elsevier.

Thompson, J. D., Gibson, T. J., Plewniak, F., Jeanmougin, F. \& Higgins, D. G. (1997). The CLUSTAL_X windows interface: flexible strategies for multiple sequence alignment aided by quality analysis tools. Nucleic Acids Res 25, 4876-4882. van der Walt, J. P. (1992). The Lipomycetaceae, a model family for phylogenetic studies. Antonie van Leeuwenhoek 62, 247-250.

van der Walt, J. P., Botha, A. \& Smith, M. Th. (1997). Lipomyces mesembrius sp. nov., a member of the $L$. starkeyi species-complex. Antonie van Leeuwenhoek 71, 325-328.

van der Walt, J. P., Smith, M. Th. \& Roeijmans, H. J. (1999). Four new species in Lipomyces. Syst Appl Microbiol 22, 229-236.

Yamada, Y. \& Kondo, K. (1973). Coenzyme Q system in the classification of the yeast genera Rhodotorula and Cryptococcus, and the yeast-like genera Sporobolomyces and Rhodosporidium. J Gen Appl Microbiol 19, 59-77.

Yarrow, D. (1998). Methods for the isolation and identification of yeasts. In The Yeasts, a Taxonomic study, 4th edn, pp. 77-100. Edited by C. P. Kurtzman \& J. W. Fell. Amsterdam: Elsevier. 